\title{
Evaluating Responses of Crop Water Use, Soil Water Storage and Infiltration to Precipitation Using Insentek Probes
}

\author{
Anzhen Qin ${ }^{1}$, Dongfeng Ning ${ }^{1, *}$, Zhandong Liu ${ }^{1}$, Bin Sun ${ }^{2}$, Ben Zhao ${ }^{1}$, Junfu Xiao ${ }^{1}$ and Zugui Liu ${ }^{1}$ \\ ${ }^{1}$ Key Laboratory of Crop Water Use and Regulation, Ministry of Agriculture, Farmland Irrigation Research Institute, Chinese \\ Academy of Agricultural Sciences, Xinxiang 453002, China \\ ${ }^{2}$ Xuchang Irrigation Experiment Station, Xuchang Water Authority, Xuchang 461000, China \\ ${ }^{*}$ Corresponding author
}

\begin{abstract}
Precipitation has been shown to increase soil water storage (SWS) and soil infiltration depth (SID) while significantly restrain crop water use (i.e., crop evapotraspiration, $\left.E T_{c}\right)$ during rainy days. However, the reducing effects on $E T_{c}$ and increasing effects on SWS and SID has not been well quantified due to a lack of automatic soil moisture measurement. Insentek probe is a newly developed soil moisture monitoring equipment that achieves automatic measurement of soil moisture. This enables the calculation of SWS and SID related to precipitation. Four Insentek probes were installed in four corresponding lysimeters to monitor SWS, SID and ET for maize plants during rainy days at Xuchang Irrigation Experiment Station, in 2015 and 2016. Both lysimeter and Insentek $E_{c}$ was related to precipitation in a power function. The reducing effect of precipitation on Insentek $\mathbf{E T}_{\mathrm{c}}$ was greater compared with lysimeter ETc. The relationships between SWS increment and precipitation, and between SID and precipitation were fitted to a positively linear function. The linearity indicated that per $10 \mathrm{~mm}$ precipitation averagely increased SID by $17.9 \mathrm{~cm}$ and SWS by 7.3 $\mathrm{mm}$, respectively. We conclude that precipitation is an independent factor that determines $\mathbf{E T}_{\mathrm{c}}$ of maize on rainy days despite of current soil moisture status in semi-humid climate in the North China Plain.
\end{abstract}

Keywords-insentek; precipitation; crop water requirement; lysimetry; zea mays $L$

\section{INTRODUCTION}

Maize is known as one of the highest evapotranspiration (ET) crops both daily and seasonally around the globe [1]. Crop evapotranspiration $\left(\mathrm{ET}_{\mathrm{c}}\right)$ of maize ranges from 400 to 600 $\mathrm{mm}$ during the entire growing seasons in the North China Plain [2]. Over the past two decades in the NCP, $\mathrm{ET}_{\mathrm{c}}$ of maize has increased by $10 \%$ along with the improvement of grain yield due to the breading of new varieties and improving of agronomic practices [3]. Accurately estimating $E T_{c}$ provides valuable information for effective irrigation water management, which is essential to mitigating the fresh water shortage problem and ensuring food security for ever-growing population [4]. There exist a variety of methods available for simulating $\mathrm{ET}_{\mathrm{c}}$, including lysimeter water balance method, eddy covariance method, and thermal flux method, etc. [4-6]. Among them, large-scale precision weighing lysimeters are the most precise means to estimate $\mathrm{ET}_{\mathrm{c}}$ in a relatively high resolution through measuring weight changes of lysimeter mass.
Traditionally, $\mathrm{ET}_{\mathrm{c}}$ in a crop growth phase can be calculated using water balance equation based on soil water storage changes [4]. Soil water balance is a water exchange between soil and atmospheric interfaces, including ET standing for water loss and precipitation representing water input. Previous studies usually chose $\mathrm{ET}_{\mathrm{c}}$ on clear days to analysis relationships between $\mathrm{ET}_{\mathrm{c}}$ and soil moisture [5-6]. Data during rainy days were not included because they lacked an automatic technique to monitor soil moisture on rainy days at field scales [9]. This restricts our knowledge on how $\mathrm{ET}_{\mathrm{c}}$ responses to precipitation on rainy days. It is wrong to simply take $\mathrm{ET}_{\mathrm{c}}$ during clear days for granted to represent a seasonal total of crop water use although $\mathrm{ET}_{\mathrm{c}}$ during rainy days is relatively low. Insentek probe method is an innovative technique to automatically monitor soil moisture instead of conventional methods (e.g., neutron probe method and oven-drying method etc.). It is a kind of real-time soil moisture monitoring which transmits data wirelessly through GPRS network. However, merely were Insentek probes applied to monitor $\mathrm{ET}_{\mathrm{c}}$ during rainy days. Moreover, Insentek is a powerful means to detect soil water storage increment and soil infiltration depth due to precipitation. In this study, weighing lysimeters were adopted to continuously monitor $\mathrm{ET}_{\mathrm{c}}$ of maize along with Insentek probes. Precipitation data were recorded by a nearby weather station. We hypothesized that $\mathrm{ET}_{\mathrm{c}}, \mathrm{SWS}$ and SID during rainy days was a function of precipitation regardless of current soil moisture status. The objectives of this study is to quantify the responses of $\mathrm{ET}_{\mathrm{c}}$, SWS, SID to precipitation using Insentek probe method.

\section{MATERIALS AND METHODS}

\section{A. Site Description}

The experiment was carried out at the Xuchang Irrigation Experiment Station, North China Plain, in 2015 and 2016 $\left(34^{\circ} 76^{\prime} \mathrm{N}, 113^{\circ} 24^{\prime} \mathrm{E}\right.$, a.s.1. $\left.72.8 \mathrm{~m}\right)$. The place has a continent temperate monsoon climate. Mean annual precipitation is 640.9 $\mathrm{mm}$, of which $65 \%$ falls in the maize growing season. Mean annual temperature is $14.7{ }^{\circ} \mathrm{C}$, and annual sunshine hours are $2280 \mathrm{hr}$. Soil bulk density at $0-60 \mathrm{~cm}$ soil layer is $1.45 \mathrm{~g} \mathrm{~cm}^{-3}$ and soil organic matter at the same layer is $16.5 \mathrm{~g} \mathrm{~kg}^{-1}$. The soil is a fluvo-aquic soil with silt loam texture. Water table at the station is detected more than $5 \mathrm{~m}$ below the soil surface. 


\section{B. Experimental Design}

A popularly used maize seeds ( $c v$. Pioneer 335) were handsown on June 5, 2015 and 2016 on lysimeters. Maize was planted in row spacing of $50 \mathrm{~cm}$ and plant-to-plant spacing 30 $\mathrm{cm}$. Maize plants were thinned to 32 plants per lysimeter. Application rates of fertilizer for each lysimeter were $225 \mathrm{~kg} \mathrm{~N}$ $\mathrm{ha}^{-1}, 180 \mathrm{~kg} \mathrm{P}_{2} \mathrm{O}_{5} \mathrm{ha}^{-1}$, and $55 \mathrm{~kg} \mathrm{~K}_{2} \mathrm{O} \mathrm{ha}{ }^{-1}$, respectively. Diammonium phosphate and potassium sulfate were broadcast as base fertilizer prior to sowing. One half amount of urea was applied as base fertilizer before sowing, whereas the rest amount of nitrogen was top-dressed at heading stage. Fertilizer was incorporated into soils to a depth of $20 \mathrm{~cm}$ by hoe. Except a flood irrigation $(55 \mathrm{~mm})$ after maize sowing to guarantee seed germination, no supplemental irrigation was added to maize plants because seasonal precipitation basically met the crop water requirement in the two consecutive years. Weeds and pests control practices were applied according to the local governmental recommendations.

\section{Data Measurements and Calculations}

Crop water use $\left(\mathrm{ET}_{\mathrm{c}}\right)$ was monitored by four large precision weighing lysimeters $(2.0 \mathrm{~m}$ wide $\times 2.4 \mathrm{~m}$ long $\times 2.3 \mathrm{~m}$ in depth). The large-scale weighing lysimeter system contains a main body, load cell, and data logger system. Weighing precision was $\pm 100 \mathrm{~g}$, equal to $\pm 0.1 \mathrm{~mm}$ of water column. The resolution enables accurate determination of daily $\mathrm{ET}_{\mathrm{c}}$. The masses of lysimeters were measured every $10 \mathrm{~s}$, and the data were reported as $30-$ min means. Daily $\mathrm{ET}_{\mathrm{c}}$ was determined as the difference between the mass losses and gains on a whole day basis divided by the lysimeter area of $6.6 \mathrm{~m}^{2}$.

Insentek probes were installed at the center of each lysimeter to a depth to $1 \mathrm{~m}$. In this study, soil water storage (SWS) was a product of volumetric water content by the thickness of soil layer. For Insentek probe method, $\mathrm{ET}_{\mathrm{c}}$ was calculated based on soil water storage changes on a daily basis using soil water balance equation as follows:

$$
E T_{c}=\operatorname{Pr} e+I+W S_{d}-W S_{d+1}
$$

Where $E T_{c}$ is crop daily evapotranspiration $(\mathrm{mm}) ; P$ is precipitation $(\mathrm{mm})$ monitored by a rain gauge of the nearby weather station; $I$ is irrigation quota $(\mathrm{mm})$ measured using a flow meter installed at the outlet of a pipeline; $W S_{d}$ and $W S_{d+1}$ is soil water storage $(\mathrm{mm})$ to a depth of $1 \mathrm{~m}$ on the current and the next day, respectively.

Daily $\mathrm{ET}_{\mathrm{c}}$ during rainy days was inhibited by precipitation, especially for precipitation with amount larger than $15 \mathrm{~mm}$. In this study, $\mathrm{ET}_{\mathrm{c}}$ on rainy days was related to precipitation in a negatively power function as follows:

$$
E T_{c}=a \times \operatorname{Pr} e^{-b}
$$

Where $E T_{c}$ is crop daily evapotranspiration (mm); Pre is precipitation (mm); $a$ and $b$ are function parameters to be fitted.

Soil water storage increment ( $\triangle \mathrm{SWS})$ due to rain-water input on rainy days were estimated by subtracting SWS a day before a rainfall event from SWS on the rainfall day. The relationship between $\Delta$ SWS and precipitation was quantified using a positive linear equation:

$$
\Delta \mathrm{SWS}=a \times \operatorname{Pr} e-b
$$

Soil moisture was automatically monitored hourly by the Insentek probes, allowing for the calculation of soil infiltration depth (SID) due to precipitation. Soil water infiltration was estimated by determining the depth of soil moisture increasing one day after a rainfall event, which was easily detected by Insentek probes. The magnitudes of SID on rainy days were assumed to associate with precipitation in a positively linear manner as follows:

$$
\mathrm{SID}=a \times \operatorname{Pr} e+b
$$

\section{Statistical analysis}

Data were analyzed using analysis of variance with Statistical Analysis Software (version 19.0, SPSS Inc., Chicago, IL, USA). Significance was declared at the probability level of 0.05. Relationships among $\mathrm{ET}_{\mathrm{c}}, \mathrm{SWS}$, SID, and precipitation were analyzed by means of the Levenberg-Marquardt Algorithm.

\section{RESUlts AND DisCUSSION}

\section{A. Statistics for Precipitation and Temperature}

Because there existed no year $\times$ data interaction in maize growing seasons of both years, we averaged the two years' data for analysis. Precipitation grades were classified according to the recommendations of China Meteorological Administration (Table I). Most rainfall events fell in the light rainfall range with an average precipitation of $4.75 \mathrm{~mm} \mathrm{~d}^{-1}$ and average numbers of $26 \mathrm{~d}$. Day numbers of moderate and heavy rainfall events were 4 to $6 \mathrm{~d}$ with an average precipitation of $13.3 \mathrm{~mm}$ $\mathrm{d}^{-1}$ for moderate rainfall and $33.5 \mathrm{~mm} \mathrm{~d}^{-1}$ for heavy rainfall, respectively. In each year, there was one storm event with precipitation amount exceeding $50 \mathrm{~mm} \mathrm{~d}^{-1}$. Precipitation intensity had no significant effect on air temperature, which might be influenced by solar radiation, relative humidity and air velocity [7].

\section{B. Crop Evapotranspiration Response to Precipitation}

Both Insentek and lysimeter $\mathrm{ET}_{\mathrm{c}}$ was significantly inhibited by precipitation. Our result showed that precipitation explained $84 \%$ to $87 \%$ variations of daily $\mathrm{ET}_{\mathrm{c}}$ during rainy days regardless of current soil water content (Figure I). Moreover, precipitation, as an independent factor controlling $\mathrm{ET}_{\mathrm{c}}$, reduced $\mathrm{ET}_{\mathrm{c}}$ on rainy days in a negatively power manner. Compared to $\mathrm{ET}_{\mathrm{c}}$ during rain-free days, Insentek $\mathrm{ET}_{\mathrm{c}}$ was reduced by $30.2 \%$, $50.8 \%, 66.1 \%$, and $68.1 \%$, respectively, during light rain days, moderate rain days, heavy rain days, and storm rain days. Similarly, lysimeter $\mathrm{ET}_{\mathrm{c}}$ was reduced by $31.1 \%$, 73.2\%, 90.3\% and $93.5 \%$, respectively, during the corresponding rain days. Lysimeter $\mathrm{ET}_{\mathrm{c}}$ showed a faster response to precipitation than did Insentek $\mathrm{ET}_{\mathrm{c}}$. 


\section{Crop Evapotranspiration, Soil Water Storage Increment, and Soil Infiltration Depth Related to Precipitation}

Both lysimeter and Insentek $\mathrm{ET}_{\mathrm{c}}$ was related to precipitation in a negatively power function (Figure I). The reducing effect of precipitation on Insentek $\mathrm{ET}_{\mathrm{c}}$ was greater compared with lysimeter $\mathrm{ET}_{\mathrm{c}}$. We found that lysimeter had an immediate response to weight losses due to $\mathrm{ET}_{\mathrm{c}}$ after precipitation, weakening the sensitiveness of daily $\mathrm{ET}_{\mathrm{c}}$ total to precipitation, whereas Insentek $\mathrm{ET}_{\mathrm{c}}$ was estimated using soil water storage increment ( $\triangle \mathrm{SWS})$ occurring after soil infiltration, which needed time to finish the process. Moreover, lysimeter $\mathrm{ET}_{\mathrm{c}}$ was more sensitive to canopy transpiration than did Insentek $\mathrm{ET}_{\mathrm{c}}$. This part of weight losses also contributed to the fast response of lysimeter to actual $\mathrm{ET}_{\mathrm{c}}$ variations. The relationships between $\triangle$ SWS and precipitation, and between soil infiltration depth (SID) and precipitation were fitted to a positively linear function. The linearity indicated that per $10 \mathrm{~mm}$ precipitation averagely increased SID by $17.9 \mathrm{~cm}$ and $\Delta \mathrm{SWS}$ by $7.3 \mathrm{~mm}$, respectively (Figure II).

TABLE I. STATISTICS OF MEAN CROP EVAPOTRANSPIRATION DETERMINED BY INSENTEK PROBE METHOD AND LYSIMETRY AT DIFFERENT PRECIPITATION GRADES IN 2015 AND 2016, AT XUCHANG IRRIGATION EXPERIMENT STATION.

\begin{tabular}{|c|c|c|c|c|c|}
\hline Precipitation grades $^{\mathrm{a}}$ & No rain & Light rain & $\begin{array}{l}\text { Moderate } \\
\text { rain }\end{array}$ & $\begin{array}{c}\text { Heavy } \\
\text { rain }\end{array}$ & Storm \\
\hline Pre $^{\mathrm{b}}$ intensity $\left(\mathrm{mm} \mathrm{d}^{-1}\right)$ & 0 & $0.1-9.9$ & $10-24.9$ & $25-49.9$ & $50-99.9$ \\
\hline Mean Insen $\mathrm{ET}_{\mathrm{c}}(\mathrm{mm})$ & 3.01 & 2.1 & 1.48 & 1.02 & 0.96 \\
\hline Mean lysi $\mathrm{ET}_{\mathrm{c}}(\mathrm{mm})$ & 3.7 & 2.55 & 0.99 & 0.36 & 0.24 \\
\hline Mean $\mathrm{T}_{\text {air }}\left({ }^{\circ} \mathrm{C}\right)$ & 24.7 & 25.1 & 21.5 & 21.4 & 30.5 \\
\hline Number of days & 81 & 26 & 4 & 6 & 1 \\
\hline Mean Pre (mm) & 0 & 4.75 & 13.3 & 33.5 & 56.2 \\
\hline
\end{tabular}

b. Pre, precipitation; Tair, air temperature.

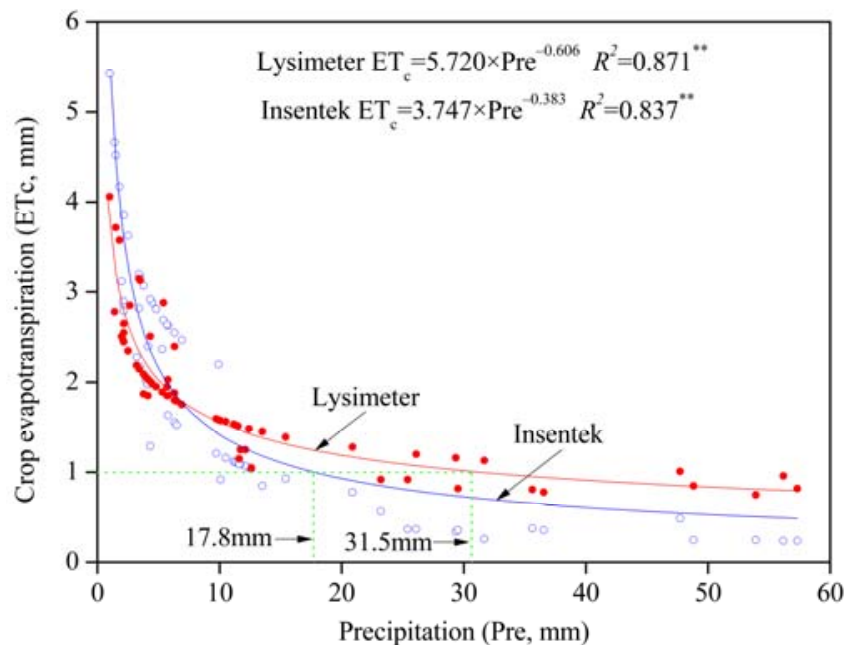

FIGURE I. RELATIONSHIP BETWEEN PRECIPITATION AND CROP EVAPOTRANSPIRATION MEASURED BY INSENTEK PROBE METHOD AND LYSIMETRY. BOTH YEARS' DATA WERE SUBJECTED FOR REGRESSION ANALYSIS

\section{Mean Daily Evapotranspiration during Different Growth Phases}

In this study, mean daily $\mathrm{ET}_{\mathrm{c}}$ were calculated for different maize growth phases in 2015 and 2016 growing seasons (i.e., emergence (VE) to six leaves (V6) phase; V6 to silking (R1) phase; R1 to milk (R3) phase; and R3 to physical maturity (R6) phase) (Table II). Daily $\mathrm{ET}_{\mathrm{c}}$ was generally considered as a representative of crop water use intensity [8]. Mean daily $\mathrm{ET}_{\mathrm{c}}$ estimated by Insentek probe method and lysimetry both peaked during V6 to R1 phase in both growing seasons, achieving an mean daily $\mathrm{ET}_{\mathrm{c}}$ of $3.56 \mathrm{~mm} \mathrm{~d}^{-1}$ (Insentek) and $4.21 \mathrm{~mm} \mathrm{~d}^{-1}$ (lysimeter) in both years. Mean daily $\mathrm{ET}_{\mathrm{c}}$ during R1 to R3 was significantly lower in 2016 than in 2015 due to continuous overcast and rainy days during that period of 2016. Significantly lowered air temperature and air velocity during overcast days gave rise to lower $\mathrm{ET}_{\mathrm{c}}$ rates [10]. Compared to lysimeter $\mathrm{ET}_{\mathrm{c}}$, Insentek probe method underestimated mean daily $\mathrm{ET}_{\mathrm{c}}$ by $15.7 \%$ and $14.6 \%$ in 2015 and 2016 , respectively.

TABLE II. MEAN DAILY EVAPOTRANSPIRATION SEPARATED BY CROP GROWTH PHASES IN MAIZE GROWING SEASONS OF 2015 AND 2016, AT XUCHANG IRRIGATION EXPERIMENT STATION.

\begin{tabular}{|c|c|c|c|c|c|}
\hline \multirow{2}{*}{ Year } & \multirow{2}{*}{ Method } & \multicolumn{4}{|c|}{ Mean Daily Evapotranspiration $\left(\mathrm{mm} \mathrm{d}^{-1}\right)$} \\
\hline & & $V E$ to $V 6^{a}$ & V6 to $R 1$ & $R 1$ to $R 3$ & $R 3$ to $R 6$ \\
\hline \multirow{2}{*}{2015} & Insentek & $2.38 \mathrm{~b}^{\mathrm{b}}$ & $3.57 \mathrm{c}$ & $3.20 \mathrm{~b}$ & $2.18 \mathrm{~b}$ \\
\hline & Lysimeter & $2.52 \mathrm{~b}$ & $4.05 \mathrm{~b}$ & $4.01 \mathrm{a}$ & $2.86 \mathrm{a}$ \\
\hline \multirow{2}{*}{2016} & Insentek & $2.84 \mathrm{a}$ & $3.55 \mathrm{c}$ & $2.11 \mathrm{c}$ & $2.26 \mathrm{~b}$ \\
\hline & Lysimeter & $2.96 \mathrm{a}$ & $4.41 \mathrm{a}$ & $2.46 \mathrm{c}$ & 2.77 \\
\hline
\end{tabular}

b. Different letters in each column indicate significant difference at $\mathrm{P}<0.05$.

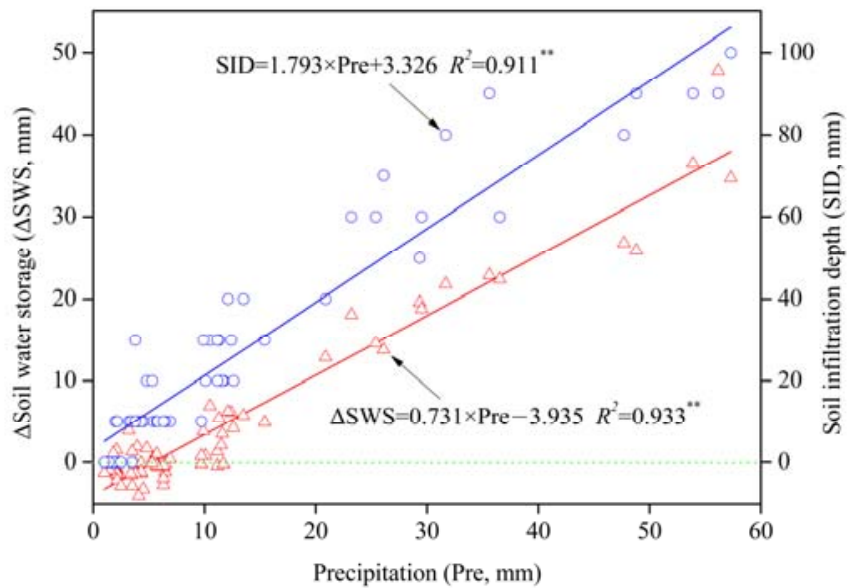

FIGURE II. RELATIONSHIP BETWEEN PRECIPITATION AND SOIL INFILTRATION DEPTH, AND BETWEEN PRECIPITATION AND SOIL WATER STORAGE INCREMENT ESTIMATED USING INSENTEK PROBE METHOD. BOTH YEARS' DATA WERE SUBJECTED FOR REGRESSION ANALYSIS.

\section{E. General Discussion}

Insentek probe method had several advantages over lysimetry, including the ease of deployment, lower initial expense, and wireless transmission of data. However, there still existed limitations for Insentek method to precisely simulate $\mathrm{ET}_{\mathrm{c}}$. For example, Insentek method led to a weaker $\mathrm{ET}_{\mathrm{c}}$ response to precipitation as the probe needs time to detect rainwater infiltration and soil water storage increment in comparison to direct measurement of weight losses of lysimeter. This led to lower daily $\mathrm{ET}_{\mathrm{c}}$ rates during rainy days using Insentek probes, as demonstrated by a $15 \%$ 
underestimate of mean daily $\mathrm{ET}_{\mathrm{c}}$ by Insentek probe method. Alternatively, one probable method to improve accuracy of Insentek $\mathrm{ET}_{\mathrm{c}}$ data was to adopt longer Insentek probes comparable to the depth of lysimeter soil column, instead of 1 $\mathrm{m}$ long Insentek probes.

Previous studies usually chose $\mathrm{ET}_{\mathrm{c}}$ rate during clear days to compare simulated $\mathrm{ET}_{\mathrm{c}}$ rates by neutron probe method, eddy covariance method, and lysimetry etc [11-13]. They often neglected the reducing effect of precipitation on actual $\mathrm{ET}_{\mathrm{c}}$ rates on field scale due to a lack of automatic soil moisture measurement technique [14]. Also, problems about infrequent measurements with neutron probe method can be well solved by Insentek automatic soil water probes, allowing accurate estimates of $\mathrm{ET}_{\mathrm{c}}$ during rainy days at daily and sub-daily intervals [15-16]. In this study, we found that simulated $\mathrm{ET}_{\mathrm{c}}$ from precipitation data during rainy days was significantly lower than expected because precipitation markedly inhibits actual $\mathrm{ET}_{\mathrm{c}}$. Therefore, we shifted our attention to the relationship between daily $\mathrm{ET}_{\mathrm{c}}$ and precipitation. We found that precipitation can be an independent factor determining daily $\mathrm{ET}_{\mathrm{c}}$ on rainy days despite of the current soil water status. Therefore, $\mathrm{ET}_{\mathrm{c}}$ during rainy days can be derived from precipitation data only, and the simulation results are in good agreement with the $\mathrm{ET}_{\mathrm{c}}$ data measured by lysimeters.

\section{CONCLUSIONS}

In semi-humid regions of China, precipitation plays an important role in soil water balance calculation of $\mathrm{ET}_{\mathrm{c}}$. In this study, daily $\mathrm{ET}_{\mathrm{c}}$ was related to precipitation in a negatively power function, whereas the relationships between $\triangle \mathrm{SWS}$ and precipitation, and between SID and precipitation were fitted to a positively linear function. Response of Insentek probes to precipitation was slower than did the lysimeters, resulting lower $\mathrm{ET}_{\mathrm{c}}$ rates by Insentek probe method. Since $\mathrm{ET}_{\mathrm{c}}$ from precipitation data during rainy days was significantly lower than expected, precipitation can be an independent factor determining daily $\mathrm{ET}_{\mathrm{c}}$ during rainy days. Till now, few studies have been conducted to quantify the responses of crop water use, soil water storage increment and soil infiltration depth to precipitation for maize plants in the North China Plain. This study starts to fill this gap.

\section{ACKNOWLEDGMENT}

This research was financially supported by the National Key Research and Development Program (2017YFD0301102), the China Agriculture Research System (CARS-02), the Agricultural Science and Technology Innovation Program (ASTIP), and the Central Public-interest Scientific Institution Basal Research Fund (Farmland Irrigation Research Institute, CAAS, FIRI2017-05).

\section{REFERENCES}

[1] T. Howell, S. R. Evett, J. A. Tolk, A. D. Schneider, and J. LSteiner, "Evapotranspiration of corn, southern high plains," In: C. R. Camp, E. J. Sadler, R. Yoder, (Eds.), "Evapotranspiration and Irrigation Scheduling," Am. Soc. Agric. Eng., St. Joseph, MI, pp. 158-166, 1996.

[2] Y. Liu, and L. Yi, "A consolidated evaluation of the FAO-56 dual crop coefficient approach using the lysimeter data in the North China Plain," Agric. Water Manage., vol. 97, pp. 31-40, 2010.

[3] X. Y. Zhang, S. Y. Chen, D. Pei, M. Y. Liu, and H. Y. Sun, "Improved water use efficiency associated with cultivars and agronomic management in the North China Plain,” Agron. J., vol. 97, pp. 783-790, 2005.

[4] X. Y. Zhang, S. Y. Chen, H. Y. Sun, Y. M. Wang, and L. W. Shao, "Water use efficiency and associated traits in winter wheat cultivars in the North China Plain," Agric. Water Manage., vol. 97, pp. 1117-1125, 2010.

[5] S. R. Evett, W. P. Kustas, P. H. Gowda, J. H. Prueger, and T. A. Howell, "Overview of the Bushland Evapotranspiration and Agricultural Remote sensing Experiment 2008 (BEAREX08): A field experiment evaluating methods quantifying ET at multiple scales," Adv. Water Resour., vol. 50, pp. 4-19, 2012.

[6] R. Ding, S. Kang, F. Li, Y. Zhang, L. Tong, and Q. Sun, "Evaluating eddy covariance method by large-scale weighing lysimeter in a maize field of Northwest China," Agric. Water Manage., vol. 98, pp. 87-95, 2010.

[7] G. Stanhill, R. Rosa, and S. Cohen, "The roles of water vapour, rainfall and solar radiation in determining air temperature change measured at Bet Dagan, Israel between 1964 and 2010,” Int. J. Climatol., vol. 33, pp. 1772-1780, 2013.

[8] Z. Liu, A. Qin, J. Zhang, J. Sun, D. Ning, and B. Zhao, et al., "Maize yield as a function of water availability across precipitation years in the North China Plain,” Crop Sci., vol. 57, pp. 2226-2237, 2017.

[9] S. R. Evett, R. C. Schwartz, J. A. Tolk, and T. A. Howell, "Soil profile water content determination: spatiotemporal variability of electromagnetic and neutron probe sensors in access tubes," Vadose Zone J., vol. 8, pp. 926-941, 2009.

[10] S. R. Evett, R. C. Schwartz, T. A. Howell, R. L. Baumhardt, and K. S. Copeland, "Can weighing lysimeter ET represent surrounding field ET well enough to test flux station measurements of daily and sub-daily ET?” Adv. Water Resour., vol. 50, pp. 79-90, 2012.

[11] S. R. Evett, J. A. Tolk, and T. A. Howell, "A depth control stand for improved accuracy with the neutron probe," Vadose Zone J., vol. 2, pp. 642-649, 2003.

[12] J. A. Tolk, and S. R. Evett, "Lysimetry versus neutron moisture meter for evapotranspiration determination in four soils," Soil Sci. Soc. Am. J., vol. 73, pp. 1693-1698, 2009.

[13] S.R. Evett, R. C. Schwartz, R. J. Lascano, and M. G. Pelletier, "In-soil and down-hole soil water sensors: Characteristics for irrigation management," In Proceedings of 5th Decennial National Irrigation Symposium, pp. 5-8, Dec. 2010, Phoenix, Arizona. Paper No. IRR108346. ASABE, St. Joseph, Mich. 2010.

[14] T. A. Howell, S. R. Evett, J. A. Tolk, and A. D. Schneider, "Evapotranspiration of full-, deficit-irrigated, and dryland cotton on the northern Texas High Plains,” J. Irrig. Drainage Eng., vol.130, pp. 277285,2004

[15] S. R. Evett, "Neutron moisture meters," In: S. R. Evett, L. K Heng, and P. Moutonnet, (Eds.), "Field Estimation of Soil Water Content: A Practical Guide to Methods, Instrumentation, and Sensor Technology," International Atomic Energy Agency, Vienna, Austria, Chapters 2-3, 2008.

[16] S. R. Evett, T. A. Howell, A. D. Schneider, D. F. Wanjura, and D. R. Upchurch, "Water use efficiency regulated by automatic drip irrigation control," In: "2001 Proceedings of International Irrigation Show," October 31-November 7, San Antonio, TX. The Irrigation Association, Falls Church, Virg., pp. 49-56, 2001. 